\title{
Islet Abnormalities Associated with an Early Influx of Dendritic Cells and Macrophages in NOD and NODscid Mice
}

\author{
Judith G. M. Rosmalen, Françoise Homo-Delarche, Sylvie Durant, Marcel Kap, \\ Pieter J. M. Leenen, and Hemmo A. Drexhage \\ Department of Immunology (JGMR, MK, PJML, HAD), Erasmus University, Rotterdam, The Netherlands; and CNRS \\ UMR 8603 (FH-D, SD), Université Paris V, Hôpital Necker, Paris, France
}

SUMMARY: In the nonobese diabetic (NOD) mouse model for type 1 diabetes, the inflammatory infiltration of islets starts with an influx of dendritic cells $(\mathrm{DC})$ and macrophages $(\mathrm{M} \phi)$ at approximately 4 weeks of age. Around this time, NOD mice show endocrine abnormalities, indicated by a transient hyperinsulinemia that lasts until 8 weeks of age. Subsequently, they develop abnormally large islets of Langerhans, here designated as "mega-islets." NODscid mice, which lack functional lymphocytes, also exhibit transient hyperinsulinemia, but to a lesser extent. First, to determine the role of lymphocytes in the morphological islet abnormalities, we compared 6-week-old (prediabetic) NOD and NODscid females regarding mega-islet development and accumulation of antigen-presenting cells (APC), particularly CD11c ${ }^{+} \mathrm{DC}$ and ERMP23 ${ }^{+} \mathrm{M} \phi$. In NODscid mice, early APC infiltration and mega-islets were present, but less marked compared with NOD mice, thus suggesting a role of lymphocytes in mega-islet formation. In both NOD and NODscid mice, the APC infiltration was predominantly found around the mega-islets, suggesting a relationship between both parameters. Second, to analyze the role of $\beta$-cell hyperactivity in mega-islet formation, we studied the effect of short-term prophylactic insulin treatment on these parameters. Prophylactic insulin treatment decreased the percentages of mega-islets in both NOD and NODscid mice, indicating that $\beta$-cell hyperactivity is also involved in mega-islet formation. In conclusion, mega-islet formation in mice with the NOD genetic background takes place under the influence of both $\beta$-cell hyperactivity and leukocytes. (Lab Invest 2000, 80:769-777).

$$
T
$$
ype 1 diabetes mellitus is a T-cell-mediated autoimmune disease, in which the insulinproducing cells in the islets of Langerhans are attacked and destroyed by infiltrating leukocytes (Atkinson and Maclaren, 1994; Bach, 1995; Tisch and McDevitt, 1996). The disease is characterized by a long pre-clinical period; symptoms of diabetes only develop when less than $10 \%$ of the $\beta$-cell mass is left. During this pre-clinical period, various autoantibodies directed against $\beta$-cell antigens, including insulin and GAD (Harrison, 1994; Lernmark et al, 1993; Roep, 1996), are circulating. This pre-clinical period provides an opportunity for prediction and prevention, and therefore needs intensive study.

The nonobese diabetic (NOD) mouse is a commonly used spontaneous model for type 1 diabetes (Bach, 1995). In this model, the first recognized sign of autoimmunity is infiltration of antigen-presenting cells (APC) in and around pancreatic islets (Homo-Delarche and Boitard, 1996; Jansen et al, 1994). These APC include dendritic cells (DC) as well as macrophages

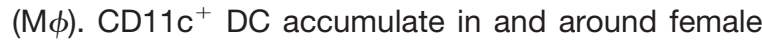

Received February 23, 2000.

Address reprint requests to: Dr. J. G. M. Rosmalen, Department of Immunology, Erasmus University Rotterdam, P.O. Box 1738, 3000 DR Rotterdam, The Netherlands. Fax: $31 \quad 10408$ 9456; E-mail: rosmalen@immu.fgg.eur.nl
NOD islets from 3 to 7 weeks of age onwards. Simultaneously, ER-MP23 ${ }^{+} \mathrm{M} \phi$, which are normally present in the connective tissue in the NOD pancreas, migrate to the periphery of the islets (Jansen et al, 1994). This early accumulation of cells (of which the majority is presumably monocyte-derived) plays an essential role in the development of the insulitis, because prevention of the early influx of monocytes stops the process (Hutchings et al, 1990). Only after this early (peri-)islet accumulation of $\mathrm{DC}$ and $\mathrm{M} \phi$, large numbers of $\mathrm{T}$ and $B$ lymphocytes are recruited to the site, ie, in NOD females from the age of 7 to 10 weeks onwards. In the BioBreeding (BB) rat, another spontaneous animal model for type 1 diabetes, insulitis also starts with an accumulation of APC (Voorbij et al, 1989). The trigger for the early accumulation of $D C$ and $M \phi$ in the prediabetic pancreas is still unknown.

Autoimmune diseases might be caused by aberrations in the function of the immune system as well as in the target gland (Homo-Delarche and Boitard, 1996; Wick et al, 1993). In the prediabetic NOD mouse, several changes in the function of the islets of Langerhans have been described. From 4 weeks of age, prediabetic NOD mice females show signs of islet hyperfunction as evidenced by higher basal blood insulin levels and a lower glycemia as compared with mice of several control strains (Amrani et al, 1998; Homo-Delarche, 1997). Glucose tolerance tests also showed a more rapid blood insulin peak and a faster 
drop in blood glucose levels in prediabetic NOD mice compared with controls. Evidence for an early islet abnormality also has a morphological basis, because we previously showed a higher frequency of hyperplastic islets ("mega-islets") in prediabetic NOD mice compared with non-diabetic control strains (Jansen et al, 1996).

The question thus arises in what manner endocrine islet abnormalities are related to the development of autoimmunity. We asked whether an association exists between islet hyperplasia, as a morphological sign of islet abnormality, and the development of the inflammatory infiltrate. To address this question, we compared the development of islet hyperplasia (mega-islet development) in NOD and NODscid mice. The latter lack mature $\mathrm{T}$ and $\mathrm{B}$ cells due to the scid mutation, and thus develop neither lymphocyte insulitis nor diabetes (Prochazka et al, 1992). If mega-islet development would be caused by infiltrating lymphocytes, this hyperplasia would not be observed in NODscid mice. To define the relationship between infiltrating cells and islet hyperplasia more specifically, we investigated a putative correlation between infiltrates and islet size in both NOD and NODscid mice. Finally, we wondered whether the previously observed $\beta$-cell hyperactivity in itself plays a role in the formation of mega-islets. For this purpose, we used prophylactic insulin treatment that is known to decrease insulitis and diabetes incidence in rodents (Atkinson et al, 1990). In vivo administration of insulin is known to down-regulate endogenous insulin secretion (Argoud et al, 1987; Boden et al, 1993; Sai et al, 1996; Strubbe and Steffes, 1993). Prophylactic insulin treatment can thus be used as a tool to prevent the development of $\beta$-cell hyperactivity and to study mega-islet develop- ment in the absence of such hyperactivity. However, prophylactic insulin also affects tolerance induction towards islet antigens (Karounos et al, 1997). Therefore, we studied the effect of prophylactic insulin treatment on islet hyperplasia in NODscid mice in addition to NOD mice. In this way, we exclude indirect effects of prophylactic insulin treatment on islet hyperplasia via lymphocytes. The results indicated that both islet hyperactivity in itself and infiltrating lymphocytes appear to be involved in the observed mega-islet formation.

\section{Results}

\section{NOD and NODscid Mice Both Develop Increased Percentages of Mega-Islets, But This Phenomenon is Less Prominent in the NODscid Mouse}

To determine the kinetics of mega-islet development and the contribution of infiltrating cells, we first compared the development of islet sizes in NOD, NODscid, and C57BL/10 females at different ages (Fig. 1). Mega-islets were defined as islets with an area of more than 10,000 pixels at a magnification of $100 \times$. At 5 weeks of age, the percentage of mega-islets was similar in the three strains (around 10\% of the islets). Between 5 and 10 weeks of age, NOD and NODscid females developed significantly increased numbers of mega-islets (ie, $15 \%$ to $20 \%$ of the islets), whereas, in C57BL/10 mice, the percentage of mega-islets remained constant (ie, approximately $10 \%$ of the islets) ( $p<0.05$ for both NOD and NODscid vs. C57BL/10). At 15 weeks of age, NOD mice exhibited a further increase in the number of mega-islets, which reached over $20 \%$ of total islets. In contrast, in NODscid mice,

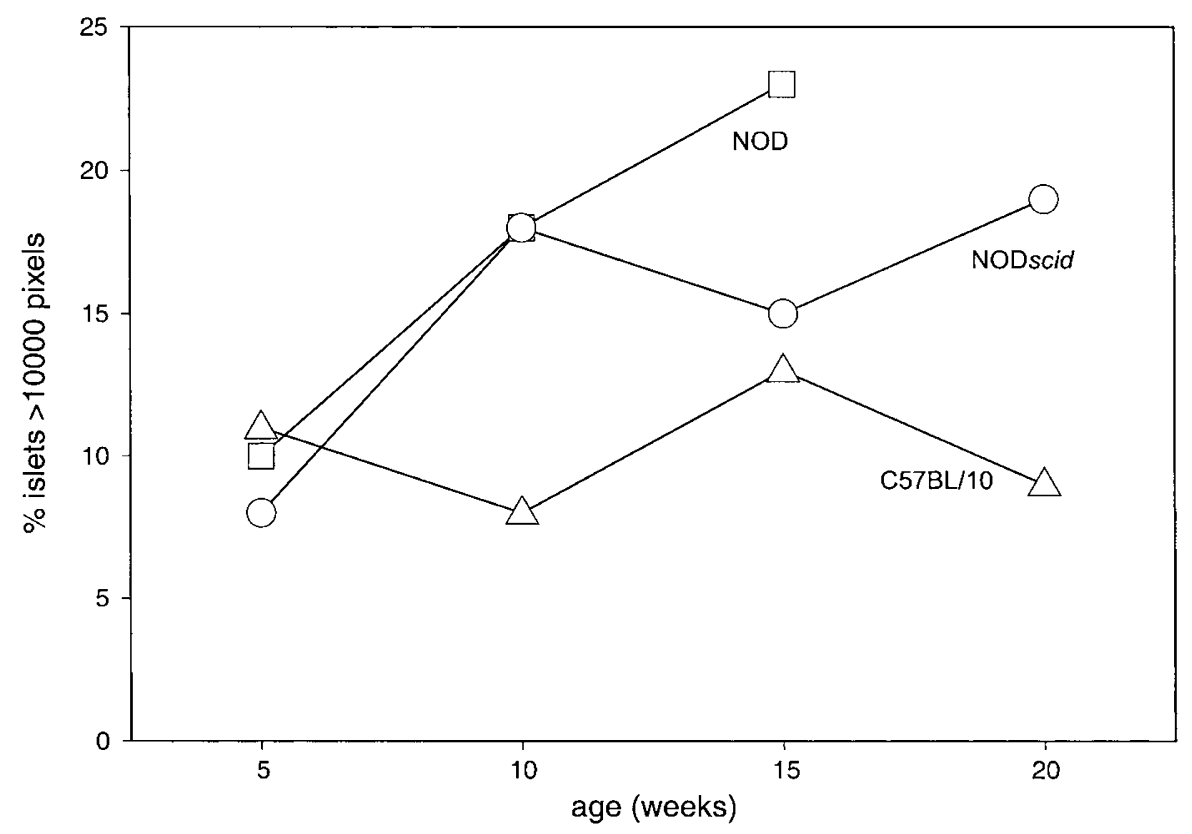

Figure 1.

Development of mega-islets, as a function of age, in nonobese diabetic (NOD), NODscid, and C57BL/10 mice ( $n=5$ mice/age group). Results are percentages of total number of islets from 5 mice in each age-strain group. 
the percentage of mega-islets remained similar between 10 and 20 weeks of age (around $15 \%$ to $20 \%$ of the islets) ( $p<0.05$ for NOD vs. NODscid). In NOD mice over 15 weeks of age, islet size could not be measured because of the presence of destructive insulitis, a phenomenon that does not take place in NODscid mice.

In conclusion, mega-islet formation takes place after 5 weeks of age in both NOD and NODscid mice and appears to correlate in time with the progression of infiltration. However, the phenomenon is less prominent in NODscid mice, suggesting a contribution of infiltrating lymphocytes to mega-islet formation.

\section{Initial Infiltration of DC, M $\phi f$ and Lymphocytes is Predominantly Associated with Mega-Islets, but is less Pronounced in NODscid Mice}

Because the start of mega-islet formation correlated in time with the initiation of a substantial leukocyte infiltration, we wanted to specify the relationship between mega-islet formation and leukocyte infiltration in more detail. Therefore, the infiltration of the islets in relation to their size was compared in NOD and NODscid females at 6 weeks of age (the time at which there is a predominant infiltration of $\mathrm{DC}$ and $\mathrm{M} \phi \mathrm{f}$ and, in NOD mice, only limited numbers of lymphocytes). The intensity of infiltration was measured in two ways.

First, the percentage of islets infiltrated with ER-

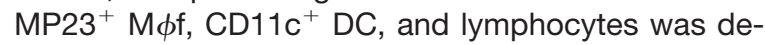
termined. CD11 $\mathrm{c}^{+} \mathrm{DC}$ and lymphocytes both do not normally occur in the pancreas of control animals at this age. Hence, every positive cell in the pancreas was considered to be an infiltrating cell and thus an islet was defined as infiltrated if at least one positive cell was situated around and/or within the islet. For ER-MP23 ${ }^{+} \mathrm{M} \phi$, this definition is different, because ER-MP23 $^{+} \mathrm{M} \phi$ are resident cells in the exocrine pancreas, but they are never localized in the islets of non-autoimmune prone control animals (Jansen et al, 1994). Therefore, for ER-MP23 ${ }^{+} \mathrm{M} \phi$, an islet was defined as infiltrated only if at least one positive cell was situated within the islet, and not if positive cells were only present around the islet.

Second, the extent of infiltration per islet was determined by measuring the size of the infiltrate. For lymphocytes, this was done by measuring the size of the lymphocyte infiltrate, which is localized next to the islet at this age (lymphocytes rarely infiltrate the islet itself at this age) (Fig. 2). For CD11c ${ }^{+} \mathrm{DC}$ and ER$\mathrm{MP}_{23}{ }^{+} \mathrm{M} \phi$, this was done by measuring the percentage of islet surface positive for the CD11c or the ER-MP23 marker. In this way, APC infiltration is expressed as a density and thus corrected for the islet size that was measured.

$\mathrm{CD}_{11 \mathrm{C}^{+}} \mathrm{DC}$ were preferentially associated with the mega-islets in 6-week-old NOD mice. The percentage of CD11 ${ }^{+}$DC-infiltrated islets was significantly higher in mega-islets compared with normal islets $(p<$ 0.001) (Fig. 3). It can, however, be argued that megaislets have a higher chance of being infiltrated by an APC solely because of the greater area measured.

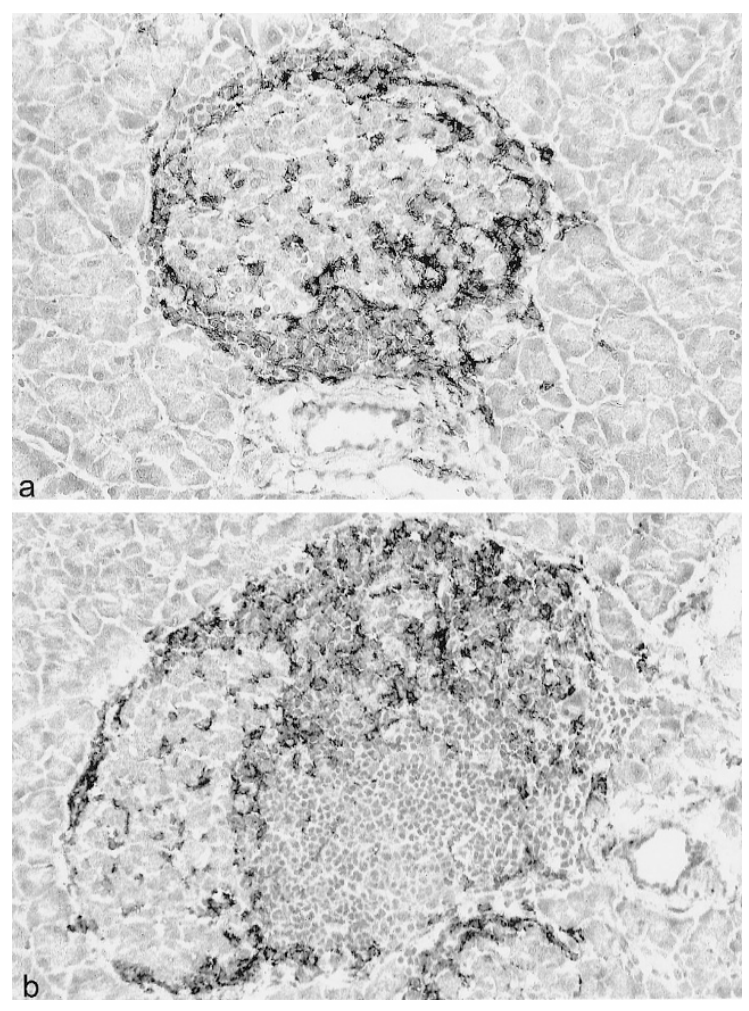

Figure 2.

Development of peri-insulitis in an NOD female at 10 weeks of age. Staining for $\mathrm{CD}_{11 \mathrm{c}^{+}}$dendritic cells $(\mathrm{DC})$, original magnification $\times 250$. Note that $\mathrm{CD} 11 \mathrm{C}^{+}$ $D C$ already infiltrate the islet at stages in which lymphocyte accumulation around the islets is relatively limited (a). Lymphocytes, in contrast, form an infiltrate adjacent to the islet, even if already high numbers of lymphocytes are present (b)

Therefore, we also looked at the density of the islet infiltration with APC in normal islets and mega-islets by expressing the CD11 ${ }^{+}$surface area related to the total islet surface area. We found that the density of infiltration with CD11c ${ }^{+}$DC was significantly higher in mega-islets compared with normal islets $(p<0.0001)$ (Table 1). To exclude the effects of lymphocytes, we determined DC-infiltration in NODscid mice. In these mice, as observed in NOD mice, the percentage of $\mathrm{CD}_{11 \mathrm{c}^{+}} \mathrm{DC}$-infiltrated islets was significantly higher in mega-islets compared with normal islets $(p=0.01)$ (Fig. 3). However, differences between NODscid and NOD mice were observed: both the percentage of

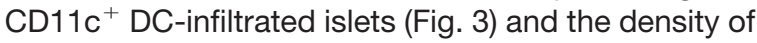
$\mathrm{CD}_{11 \mathrm{C}^{+}}$DC-islet infiltration (Table 1) were significantly reduced in NODscid compared with NOD mice ( $p=$ 0.01 and $p=0.048$, respectively).

ER-MP23 ${ }^{+} \mathrm{M} \phi$ also preferentially infiltrated megaislets in NOD mice. The percentage of ER-MP23 ${ }^{+}$ $\mathrm{M} \phi$-infiltrated islets was significantly higher in megaislets than in normal islets ( $p=0.00001)$ (Fig. 3). Furthermore, the density of ER-MP23 ${ }^{+} \mathrm{M} \phi$ infiltration in these islets was higher in mega-islets than in normal islets $(p=0.0001)$ (Table 1$)$. In NODscid mice, the percentage of ER-MP23 ${ }^{+} \mathrm{M} \phi$-infiltrated islets (Fig. 3) and the density of infiltration with ER-MP23 ${ }^{+} \mathrm{M} \phi$ (Table 1) were also significantly higher in mega-islets than in normal islets $(p=0.01$ and $p=0.02$, respec- 

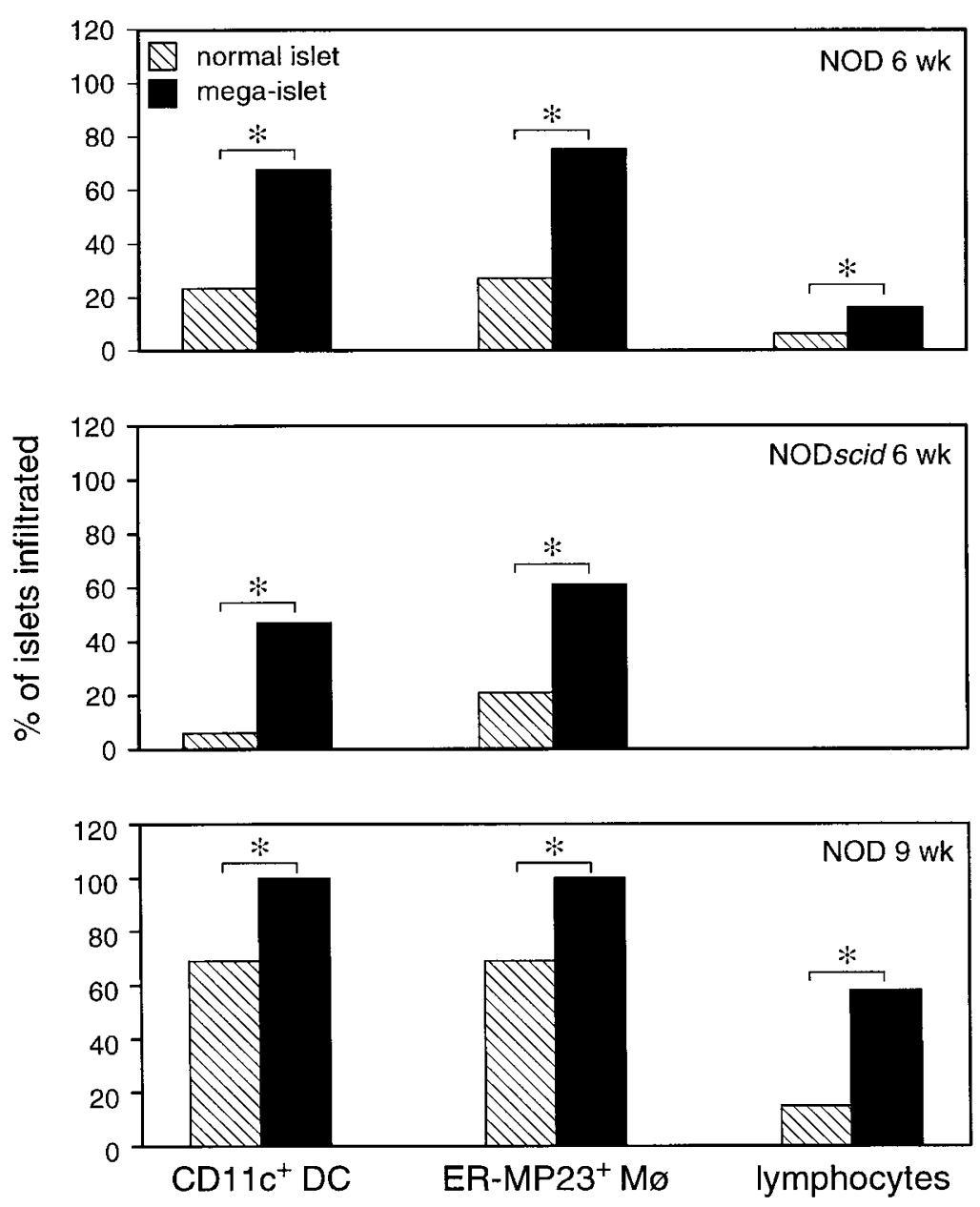

Figure 3 .

Compared with normal islets, mega-islets are preferentially infiltrated with early infiltrating APC and lymphocytes. An islet is defined as infiltrated with ER-MP23 ${ }^{+}$ macrophages $(\mathrm{M} \phi)$ if there is at least one cell detected within the islet, and defined as infiltrated with CD11c ${ }^{+}$DC or lymphocytes if there is at least one cell present within or around the islet (see Result section). Results are percentages of total number of islets from five mice in each age-strain group.

Table 1. The Density of Infiltration with CD11c ${ }^{+}$DC and ER-MP23 ${ }^{+} M \phi$ is Higher in Mega-Islets as Compared with Normal Islets in NOD and NODscid Mice at 6 Weeks of Age

\begin{tabular}{cccccc}
\hline & \multicolumn{2}{c}{$\mathrm{CD11C}^{+} \mathrm{DC}$} & & \multicolumn{2}{c}{ ER-MP23 ${ }^{+} \mathrm{M} \phi$} \\
\cline { 2 - 3 } Strain & Density range & Mean rank & & Density range & Mean rank \\
\hline NOD scid & & & & & 19 \\
Normal islets & $0-0.25$ & 16 & & $0-2.2$ & 27 \\
Mega-islets & $0-0.40$ & 18 & & $0-1.7$ & 41 \\
NOD & $0-2.4$ & 34 & & $0-2.9$ & 61 \\
Normal islets & $0-2.1$ & 55 & & $0-2.3$ & \\
Mega-islets & & &
\end{tabular}

Statistical analysis of the density of infiltration was done by the Mann-Whitney U Wilcoxon Rank Sum W test. This test orders the measurements and gives each measurement a rank number. The differences between the groups are than tested, based on their mean rank number. Mean ranks of this percentage for each group as determined by this test, as well as the range of measurements are depicted in this table. $p<0.05$.

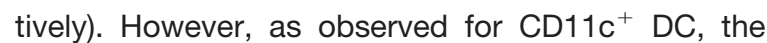
percentage of ER-MP23 ${ }^{+} \mathrm{M} \phi$ infiltrated-islets (Fig. 3) was significantly lower in NODscid compared with NOD mice $(p=0.02)$.

Although lymphocyte infiltration was minor in 6-week-old NOD mice, lymphocytes were also preferentially situated around mega-islets. The percentage of islets surrounded by lymphocytes was significantly higher in mega-islets than in normal islets $(p=0.02)$ (Fig. 3) and the area of the lymphocyte infiltrate was larger near the mega-islets as compared with the normal islets ( $p=0.001)$ (Table 2). Later, at 9 weeks of age, the percentages of infiltrated islets (Fig. 3) and the area of the lymphocyte infiltrate (Table 2) were signif- 
Table 2. The Size of the Lymphocyte Infiltrate Near Mega-Islets is Higher Than Near Normal Islets in NOD Mice 6 and 9 Weeks of Age

\begin{tabular}{cccc}
\hline & & \multicolumn{2}{c}{ Lymphocytes } \\
\cline { 3 - 4 } Strain & Age & Size range & Mean rank \\
\hline NOD & 6 weeks & & \\
& Normal islets & $0-8907$ & 87 \\
& Mega-islets & $0-28514$ & 97 \\
NOD & 9 weeks & & \\
& Normal islets & $0-59865$ & 45 \\
& Mega-islets & $0-53249$ & 68 \\
\hline
\end{tabular}

Statistical analysis of the density of infiltration was done by the MannWhitney U Wilcoxon Rank Sum W test. This test orders the measurements and gives each measurement a rank number. The differences between the groups are than tested, based on their mean rank number. Mean ranks of this percentage for each group as determined by this test, as well as the range of measurements are depicted in this table. $p<0.05$.

icantly higher in mega-islets compared with normal islets ( $p<0.001$ in both cases). As expected, lymphocytic infiltration was completely absent in NODscid mice.

In conclusion, the first infiltrating cells are preferentially found near the mega-islets. This is the case for both early infiltrating APC and lymphocytes. The association between mega-islets and early infiltrating APC can be found in NOD and NODscid mice, although APC infiltration in NODscid mice is relatively limited as compared with NOD mice.

\section{Prophylactic Insulin Treatment Prevents Mega-Islet Formation in Both NOD and NODscid Mice}

Because $\beta$-cell hyperactivity was increased before the appearance of mega-islets (Amrani et al, 1998; HomoDelarche and Boitard, 1996; Jansen et al, 1996), we wondered whether it could be a contributing factor in their formation, in addition to immune cell infiltration. We thus assessed the effect of prophylactic insulin treatment, known to down-regulate $\beta$-cell activity (Argoud et al, 1987; Boden et al, 1993; Strubbe and Steffes, 1993), in NOD and NODscid mice. In the latter, lacking functional lymphocytes, we therefore avoided the tolerizing effects of insulin on lymphocytes (Karounos et al, 1997). Figure 4 shows that prophylactic insulin treatment, administered from 3 to 6 weeks of age, decreased significantly the percentage of megaislets in NOD mice ( $p=0.003$ ), confirming previous data (Jansen et al, 1996). Moreover, it also decreased this percentage in NODscid mice to a similar extent $(p<0.001)$. It should be noted, however, that the percentages of mega-islets in both groups of placebotreated NOD and NODscid mice were higher than in untreated controls (Fig. 1). This increase in mega-islet frequency is most likely explained by the stress induced by repeated placebo injections, because an increased islet mass has been observed after repeated placebo injection (Theret, 1953).

In conclusion, down-regulating $\beta$-cell activity by means of prophylactic insulin treatment reduces

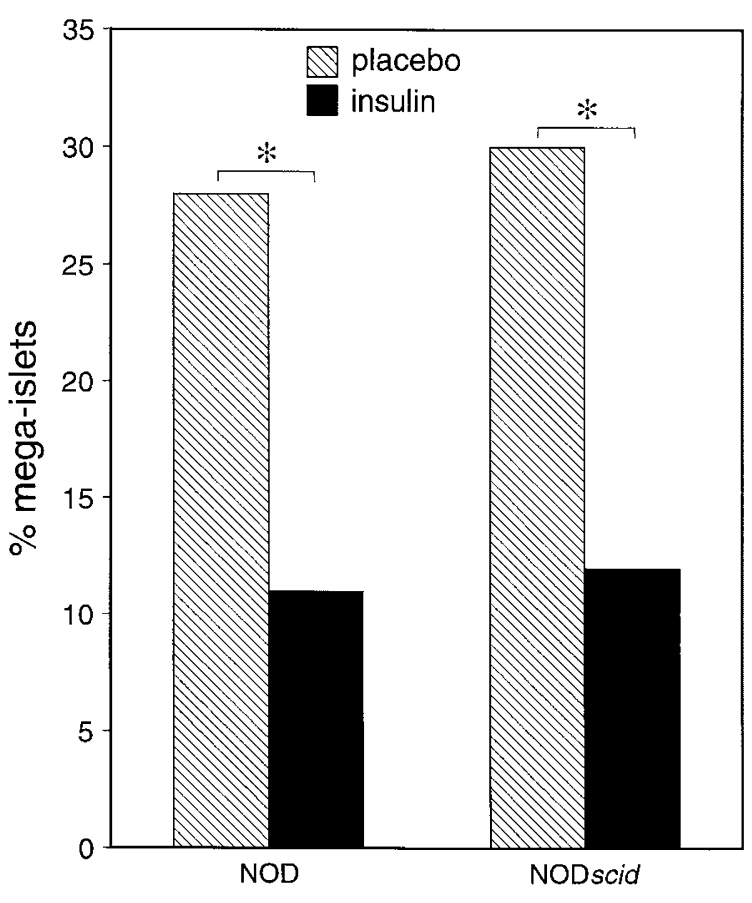

Figure 4.

Prophylactic insulin treatment prevents mega-islet development in both NOD and NODscid mice. NOD females and NODscid females were subcutaneously treated from 3 weeks to 6 weeks of age, with insulin or diluent. Results are percentages of total number of islets from eight mice in each group.

mega-islet formation in both NOD and NODscid mice. This suggests that the islet activity in itself plays a role in initiating mega-islet formation.

\section{Discussion}

In this study, we show that the largest islets or mega-islets, which are observed more frequently in NOD and NODscid mice than in controls, are preferentially associated with early infiltrating leukocytes. This concerns DC and M $\phi$ in both NOD and NODscid mice, and lymphocytes in NOD mice. In NODscid mice, mega-islet formation is less prominent than in NOD mice, suggesting that lymphocytes contribute to mega-islet formation. Moreover, $\beta$-cell metabolic activity itself appears to play a role, because its downregulation by an early and short prophylactic insulin treatment decreased the percentages of mega-islets in both NOD and NODscid strains.

In this study, we show that NOD mice had a higher fraction of mega-islets than control C57BL/10 mice. In a previous study, we observed a comparable difference using Balb/c mice as a control strain (Jansen, 1996) \#646. Moreover, our results on $\beta$-cell hyperplasia in NOD and NODscid mice are in agreement with studies showing a large $\beta$-cell mass in prediabetic NOD mice or in insulitis-free NOD stocks (NODscid, NOD-NON H-2 ${ }_{\mathrm{nb} 1}$ and NOD B2 ${ }^{\mathrm{m}}$ null (Serreze and Leiter, 1995). Mega-islet formation in NOD mice is associated in time with the appearance of the first infiltrating cells. Both the start of the $\beta$-cell hyperactivity (as assessed by increased blood insulin levels) 
and the initiation of infiltration with $\mathrm{DC}$ and $\mathrm{M} \phi$ take place around 4 weeks of age (Amrani et al, 1998; Homo-Delarche, 1997). In BB rats, there are also indications for a prediabetic $\beta$-cell hyperactivity in relation to immune infiltration. Earlier studies showed an enhanced $\beta$-cell sensitivity to glucose and an increased insulin secretion by inflamed islets from non-diabetic BB-DP rats, compared with noninflamed islets from the same or from a control strain (Teruya et al, 1993). Therefore, a period of transient islet hyperactivity and hyperplasia associated with the initiation of infiltration appears to precede $\beta$-cell exhaustion and $\beta$-cell death in both the NOD mouse and the $\mathrm{BB}$ rat.

In addition to an association in time, there is also a relationship regarding their mutual location: megaislets are preferentially associated with early infiltrating APC and lymphocytes. The association of APC infiltration and mega-islets could already be found at 6 weeks of age in NOD mice. At this age, the number of mega-islets in NOD mice is similar to that found in control mice. Because control mice do not exhibit leukocyte infiltration, it could be suggested that the NOD mega-islets function differently than the control ones. Interestingly, at this same age increased circulating insulin levels can be found in NOD mice (Amrani et al, 1998; Homo-Delarche, 1997).

Two major mechanisms could underlie the association between mega-islets and inflammatory infiltrates. First, the abnormal islet function could be the cause of APC infiltration, via, for example, insulin chemotaxis (Cavalot et al, 1993; Leiter, 1987). Second, mega-islet formation could be the consequence of the inflammatory infiltrates, via the influence of released factors. In various other endocrine organs, leukocytes have been shown to influence endocrine cell growth and/or function (Allaerts et al, 1996; Hoek et al, 1997; Simons et al, 1998). As discussed below, both mechanisms may be at play.

First, $\beta$-cell hyperactivity could contribute to the mega-islet formation by attracting leukocytes. Because insulin is known to down-regulate its own secretion (Argoud et al, 1987; Boden et al, 1993; Strubbe and Steffes, 1993) and to decrease pancreatic insulin content in NOD mice (Sai et al, 1996), we used it to prevent the transient $\beta$-cell hyperactivity that we previously described from 4 to 8 weeks of age in mice with the NOD genetic background (Amrani et al, 1998; Homo-Delarche, 1997). Here, we confirmed that prophylactic insulin treatment is able to reduce megaislet formation in NOD mice (Jansen et al, 1996). However, because the treatment could act on lymphocytes, via the induction of tolerance to insulin (Karounos et al, 1997), we also prophylactically treated NODscid mice, which lack functional lymphocytes. Insulin treatment was able to prevent mega-islet formation in NODscid mice as efficiently as in NOD mice. These results therefore suggest a role for $\beta$-cell hyperactivity in mega-islet formation.

Second, we assessed whether leukocytes could influence mega-islet formation. The results obtained in NODscid mice shows that this mechanism is also playing a role. Although both NOD and NODscid females showed an early DC and $\mathrm{M} \phi$ infiltration and an early hyperinsulinism (Amrani et al, 1998; HomoDelarche, 1997), later followed by the presence of mega-islets, nevertheless, clear differences were observed between the two strains. The first difference is the reduced infiltration of CD11 $\mathrm{C}^{+} \mathrm{DC}$ and ER-MP23 ${ }^{+}$ $\mathrm{M} \phi$ in NODscid females. Lower levels of CD11C ${ }^{+}$and $\mathrm{F} 4 / 80^{+}$cells were also suggested in another study (Dahlen et al, 1998), and the differences are thus quantified here. One explanation for this reduced APC infiltration might be related to the decreased function of APC in NODscid mice. Indeed, APC isolated from NODscid islets are much less effective in stimulating diabetogenic $T$ cell clones than those isolated from NOD islets. Transfer of diabetogenic $T$ cell clones in vivo improves the antigen-presenting function of NODscid islet APC (Shimizu et al, 1995). Thus, lymphocytes and/or their products regulate the function and phenotype of APC. The second difference between the two strains is that NODscid females not only showed a reduced APC infiltration, but also showed a less pronounced hyperinsulinism (Amrani et al, 1998) and fewer mega-islets. Indeed, mega-islet formation is higher in NOD than in NODscid mice only after 10 weeks, ie, a few weeks after the beginning of the lymphocyte infiltration that then regularly progresses. These data, therefore, suggest an in vivo stimulatory effect of the lymphocyte compartment on islet cell function and growth in NOD mice.

In conclusion, a close association is shown for the first time between early target organ abnormalities and the initiation of leukocyte infiltration in a spontaneous model of type 1 diabetes. The precise sequence of cellular events is still unknown, but the differences between NOD strains (NOD and NODscid) and control strains show that some inherent degree of $\beta$-cell hyperactivity exists. It has been suggested previously that a period of islet hyperactivity may be crucial in the development of autoimmunity (Homo-Delarche and Boitard, 1996). Hyperactive $\beta$ cells are more prone to autoimmune reactions because of high levels of autoantigens, adhesion, and $\mathrm{MHC}$ molecules and because of a higher sensitivity to cytokine-induced damage (Aaen et al, 1990; Buschard, 1991; HomoDelarche and Boitard, 1996; Palmer et al, 1989). The importance of the target gland abnormality for diabetes development is also indicated by the fact that both hyperinsulinemia and mega-islet formation are more pronounced in diabetes-prone NOD females compared with less diabetes-prone NOD males. In line with this, orchidectomy of NOD males leads to increased percentages of mega-islets and a higher diabetes incidence (manuscript submitted). This initial target organ abnormality could attract APC (and lymphocytes in NOD mice), which in turn cause a further stimulation of islet activity. Such a view is supported by the association of infiltrates and mega-islets and by the differences in mega-islet formation between NOD mice (with high APC and lymphocyte infiltration) and NODscid mice (with limited APC and no lymphocyte infiltration). The resulting $\beta$-cell exhaustion and/or de- 
struction would trigger the $\beta$ cell activity of other still unaffected islets, to maintain normal blood glucose levels. Thus, a vicious circle may have started, resulting in clinical onset of diabetes.

\section{Materials and Methods}

\section{Animals}

NOD, NODscid, and C57BL/10 female mice were bred under specific pathogen-free conditions at the facilities of the Hôpital Necker in Paris, France. The animal facilities and care followed the norms stipulated by the European Community. The incidence of diabetes in the NOD colony is, by 200 days of age, $80 \%$ for females and $40 \%$ for males. Mice were killed at 5, 10, 15 , or 20 weeks of age for the assessment of islet size without any treatment, and at 6 weeks of age for the evaluation of the $\mathrm{DC}, \mathrm{M} \phi$, and lymphocyte infiltration in relation to islet size after treatment (placebo or insulin).

\section{Insulin Treatment}

Sixteen NOD females and 16 NODscid females were treated from 3 weeks (weaning) to 6 weeks of age. In this group, eight NOD females and eight NODscid females were treated with $0.25 \mathrm{U}$ Protamine-Zincinsulin (Organon, Oss, The Netherlands) per day, eight mice from each strain served as controls and were treated with the same volume of vehicle (placebotreated group). All mice were weighed and assessed for glycemia at 3 and 6 weeks of age. Prediabetic NOD mice (with basal nonfasting glycemia $<11 \mathrm{mmol} / \mathrm{l}$, as assessed by Glukotest; Boehringer-Mannheim, Mannheim, Germany) were used only for immunohistochemical analyses.

\section{Antibodies}

ER-MP23, identifying mouse macrophage galactose specific $(\mathrm{MMGL})^{+} \mathrm{MHC}$-class $\mathrm{II}^{+} \mathrm{M} \phi$ (Jansen et al, 1994; Leenen et al, 1996), was used as a rat-antimouse hybridoma culture supernatant. N418, identifying CD11C ${ }^{+}$DC (Leenen et al, 1996), was used as a hamster-anti-mouse hybridoma culture supernatant. $\beta$ cells were identified by guinea-pig anti-porcine-insulin polyclonal antibody (Dako Glostrup, Denmark), which was used diluted 1:250 in phosphate buffered saline (PBS) with $0.1 \%$ Tween (PBS/Tween; Merck, Darmstadt, Germany). ER-MP23 was detected with horseradish peroxidase (HRP)-conjugated rabbit-anti-rat immunoglobulins (Dako). N418 was detected with HRP-conjugated goat-anti-hamster immunoglobulins (Jackson ImmunoResearch Laboratories, West Grove, Pennsylvania,). Anti-insulin was detected with HRPconjugated rabbit-anti-guinea pig immunoglobulins (Dako).

\section{Immunohistochemistry}

Mice were killed by cervical dislocation after rapid retro-orbital bleeding. Their pancreases were re- moved, embedded in OCT (Sakura, Zoeterwoude, The Netherlands) compound and frozen in $n$-hexane on dry-ice chilled alcohol. Tissues were stored at $-80^{\circ} \mathrm{C}$ until immunohistochemistry was performed. Before sectioning, microscopic slides were coated with a solution of $0.1 \%$ gelatin $/ 0.01 \%$ chromium-alum. Pancreas cryostat sections of $6 \mu \mathrm{m}$ were prepared from central regions of the pancreas that included sufficient numbers of islets. Only one section of each pancreas was stained and measured to assure that an individual islet was not examined more than once. Sections were fixed for 2 minutes in $2 \%$ hexazotized pararosaniline (Sigma, St. Louis, Missouri) (De Jong et al, 1991). After a wash with PBS with $0.1 \%$ Tween-20 (PBS/Tween; Merck), slides were incubated with first-step monoclonal antibodies for 30 minutes at room temperature in a moist chamber. Subsequently, slides were washed with PBS/Tween and incubated with second-step antibodies in the presence of $2 \%$ normal mouse serum for 30 minutes at room temperature. After an additional wash with PBS/Tween, slides were incubated with $0.05 \%$ (wt/vol) Ni-di-amino-benzidine (NiDAB; Sigma) with $0.02 \% \mathrm{H}_{2} \mathrm{O}_{2}$ and washed in PBS/ Tween after 3 minutes. Finally, slides were counterstained for 3 minutes in nuclear fast red, washed in water, dehydrated in a graded ethanol series, and mounted. For each series of pancreas sections, one slide was stained with second antibody only as a control for endogenous peroxidase activity and non-specific binding of the second step. A section of spleen was included as a positive control.

\section{Quantification of Immunohistochemistry}

The surface area of the islets and the infiltrate, as well as the percentage of islet surface positive for CD11 $\mathrm{c}^{+}$ $\mathrm{DC}$ or ER-MP23 ${ }^{+} \mathrm{M} \phi$ were assessed via a VIDAS-RT image analysis system (Kontron Elektronik GmbH/Carl Zeiss, Weesp, The Netherlands). Measurements were performed using a $100 \times$ magnification. Results of measurements were expressed in pixels. At a $100 \times$ magnification, the size of one pixel is $1.13 \times 10^{-6}$ $\mathrm{mm}^{2}$. For the measurement of islet sizes, sections were stained with anti-insulin and a nuclear fast red counterstaining. For all measurements, islets were encircled by the researcher in such a way that the whole islet was measured and not just the area positive for insulin. For the measurement of APC infiltration, sections were stained with N418 or ERMP23 and a nuclear fast red counterstaining.

\section{Statistical Analysis}

Statistical comparison of the percentage of megaislets between groups was carried out using the $\chi^{2}$ test. The Mann-Whitney U Wilcoxon Rank Sum W Test was used to determine statistical significance for differences in the absolute amount of infiltration and the $\chi^{2}$ test for differences in the percentage of large islets and the percentage of infiltrated islets. The level of significance was set as $p<0.05$. For measurements of islet size, a mean of 190 islets were analyzed 
for every age-strain group of 5 mice. For measurements of infiltration, a mean of 60 islets were analyzed for every age-strain group of 5 to 8 mice.

\section{Acknowledgements}

The authors wish to thank V. Alves, I. Cisse, and J. Coulaud for technical assistance, M. Throsby for reviewing the manuscript, T. van Os for preparing the figures, and Ms. C. Slama and Ms P. C. Assems for excellent secretarial assistance. This research was supported by grants from CNRS, Université Paris V, Fondation de France, Alfediam (associated with Lilly laboratories), NWO-INSERM, BIOMED ("Betimmune"), and the Diabetes Fonds Nederland.

\section{References}

Aaen K, Rygaard J, Josefsen K, Petersen $\mathrm{H}$, Brogren $\mathrm{CH}$, Horn T, and Buschard K (1990). Dependence of atigen expression on functional state of beta-cells. Diabetes 39: 697-701.

Allaerts W, Fluitsma DM, Hoefsmit EC, Jeucken PH, Morreau H, Bosman FT, and Drexhage HA (1996). Immunohistochemical, morphological and ultrastructural resemblance between dendritic cells and folliculo-stellate cells in normal human and rat anterior pituitaries. J Neuroendocrinol 8:17-29.

Amrani A, Durant S, Throsby M, Coulaud J, Dardenne M, and Homo-Delarche F (1998). Glucose homeostasis in the nonobese diabetic mouse at the prediabetic stage. Endocrinology 139:1115-1124.

Argoud GM, Schade DS, and Eaton RP (1987). Insulin suppresses its own secretion in vivo. Diabetes 36:959-962.

Atkinson MA, and Maclaren NK (1994). The pathogenesis of insulin-dependent diabetes mellitus. $\mathrm{N}$ Engl $\mathrm{J}$ Med 331: 1428-1436.

Atkinson MA, Maclaren NK, and Luchetta R (1990). Insulitis and diabetes in NOD mice reduced by prophylactic insulin therapy. Diabetes 39:933-937.

Bach JF (1995). Insulin-dependent diabetes mellitus as a beta-cell targeted disease of immunoregulation. J Autoimmun 8:439-463.

Boden G, Chen X, DeSantis R, Kolaczynski J, and Morris M (1993). Evidence that suppression of insulin secretion by insulin itself is neurally mediated. Metabolism 42:786-789.

Buschard K (1991). The functional state of the beta cells in the pathogenesis of insulin- dependent diabetes mellitus. Autoimmunity 10:65-69.

Cavalot F, Anfossi G, Russo I, Mularoni E, Massucco P, Burzacca S, Mattiello L, and Trovati M (1993). Insulin stimulates the polymorphonuclear leukocyte chemokinesis. Horm Metab Res 25:321-322.

Dahlen E, Dawe K, Ohlsson L, and Hedlund G (1998). Dendritic cells and macrophages are the first and major producers of TNF-alpha in pancreatic islets in the nonobese diabetic mouse. J Immunol 160:3585-3593.

De Jong JP, Voerman JS, Leenen PJ, Van der Sluijs-Gelling AJ, and Ploemacher RE (1991). Improved fixation of frozen lympho-haemopoietic tissue sections with hexazotized pararosaniline. Histochem J 23:392-401.
Harrison LC (1994). Islet cell antibodies: Light at the end of the tube? [Comment]. Diabetes Care 17:1220-1222.

Hoek A, Allaerts W, Leenen PJ, Schoemaker J, and Drexhage HA (1997). Dendritic cells and macrophages in the pituitary and the gonads. Evidence for their role in the fine regulation of the reproductive endocrine response. Eur $\mathrm{J}$ Endocrinol 136:8-24.

Homo-Delarche F (1997). Beta-cell behaviour during the prediabetic stage. Part II. Non-insulin-dependent and insulindependent diabetes mellitus. Diabetes Metab 23:473-505.

Homo-Delarche F, and Boitard C (1996). Autoimmune diabetes: The role of the islets of Langerhans. Immunol Today 17:456-460.

Hutchings P, Rosen H, O'Reilly L, Simpson E, Gordon S, and Cooke A (1990). Transfer of diabetes in mice prevented by blockade of adhesion-promoting receptor on macrophages. Nature 348:639-642.

Jansen A, Homo-Delarche F, Hooijkaas H, Leenen PJ, Dardenne M, and Drexhage HA (1994). Immunohistochemical characterization of monocytes-macrophages and dendritic cells involved in the initiation of the insulitis and beta-cell destruction in NOD mice. Diabetes 43:667-675.

Jansen A, Rosmalen JG, Homo-Delarche F, Dardenne M, and Drexhage HA (1996). Effect of prophylactic insulin treatment on the number of ER-MP23+ macrophages in the pancreas of NOD mice: Is the prevention of diabetes based on beta-cell rest? J Autoimmun 9:341-348.

Karounos DG, Bryson JS, and Cohen DA (1997). Metabolically inactive insulin analog prevents type I diabetes in prediabetic NOD mice. J Clin Invest 100:1344-1348.

Leenen PJM, Kraal G, and Dijkstra CD (1996). Markers of rodent myeloid cells. In: Lefkovits I, editor. Immunology methods manual. San Diego: Academic Press, 2467-2495.

Leiter EH (1987). Murine macrophages and pancreatic beta cells: Chemotactic properties of insulin and beta-cytostatic action of interleukin 1. J Exp Med 166:1174-1179.

Lernmark A, Moller C, Kockum I, and Sanjeevi C (1993). Islet cell autoimmunity. J Intern Med 234:361-369.

Palmer JP, Helqvist S, Spinas GA, Molvig J, MandrupPoulsen T, Andersen HU, and Nerup J (1989). Interaction of beta-cell activity and IL-1 concentration and exposure time in isolated rat islets of Langerhans. Diabetes 38:1211-1216.

Prochazka M, Gaskins HR, Shultz LD, and Leiter EH (1992). The nonobese diabetic scid mouse: Model for spontaneous thymomagenesis associated with immunodeficiency. Proc Natl Acad Sci U S A 89:3290-3294.

Roep BO (1996). T-cell responses to autoantigens in IDDM: The search for the Holy Grail. Diabetes 45:1147-1156.

Sai P, Damage C, Rivereau AS, Hoeltzel A, and Gouin E (1996). Prophylactic oral administration of metabolically active insulin entrapped in isobutylcyanoacrylate nanocapsules reduces the incidence of diabetes in nonobese diabetic mice. J Autoimmun 9:713-722.

Serreze DV, and Leiter EH (1995). Insulin-dependent diabetes mellitus in NOD mice and BB rats: Origins in hematopoietic stem cell defects and implications for therapy. In: Shafrir E, editor. Lessons from animal diabetes. London: SmithGordon, 59-73. 
Shimizu J, Carrasco-Marin E, Kanagawa O, and Unanue ER (1995). Relationship between beta cell injury and antigen presentation in NOD mice. J Immunol 155:4095-4099.

Simons PJ, Delemarre FG, and Drexhage HA (1998). Antigenpresenting dendritic cells as regulators of the growth of thyrocytes: A role of interleukin-1beta and interleukin-6. Endocrinology 139:3148-3156.

Strubbe JH, and Steffes AB (1993). Neural control of insulin secretion. Horm Metab Res 25:507-512.

Teruya M, Takei S, Forrest LE, Grunewald A, Chan EK, and Charles MA (1993). Pancreatic islet function in nondiabetic and diabetic BB rats. Diabetes 42:1310-1317.

Theret C (1953). Le pancreas endocrine et les agressions a distance: Actions experimentales compares de la castration, des pertubations de reseaux sympathiques peripheriques et d'injections stressantes non specifiques. Biol Med 42:609-652.
Tisch R, and McDevitt H (1996). Insulin-dependent diabetes mellitus. Cell 85:291-297.

Voorbij HA, Jeucken PH, Kabel PJ, De Haan M, and Drexhage HA (1989). Dendritic cells and scavenger macrophages in pancreatic islets of prediabetic BB rats. Diabetes 38:16231629.

Wick G, Hu Y, Schwarz S, and Kroemer G (1993). Immunoendocrine communication via the hypothalamo-pituitaryadrenal axis in autoimmune diseases. Endocr Rev 14:539563. 